\title{
SYNTHESIS AND OPTIMIZATION OF LOUVER-DRIVING MECHANISM FOR INNOVATIVE DAYLIGHTING SYSTEM IN DEEP- PLAN BUILDING
}

\author{
Mohammadjavad Mahdavinejad \\ Department of Architecture, Tarbiat Modares University, Tehran, Iran \\ mahdavinejad@modares.ac.ir \\ Sahar Mohammadi \\ Department of Architecture, Tarbiat Modares University, Tehran, Iran
}

\begin{abstract}
Optimum usage of daylight plays a an importatnt role in high-performance architecture and planning. Innovative daylighting systems in contemporary buildings can produce various benefits such as maximizing daylight penetration, optimizing visual comfort and reducing energy consumption. This paper is to develop a new louver-driving mechanism to optimize adoption of daylight in deep-plan building in order to meet requirements of high-performance architecture. Methodology of the paper emphasize on a experimental and quasiexperimental approach for examination of different types of louver-driving mechanism. The greater city of Tehran adopted as case study of the paper. The main goal is based on searching standards to better louver design in order to optimize energy demands by using this shading device. Thus 45 different cases with different louver width and angles and different louvers' distance from façade were chosen to analysis.Visual comfort and energy efficiency are analysed in an integrated approach. Moreover the combination of daylight and energy performances has always been an issue, as different software packages are needed to perform detailed calculations. A simplified method to overcome both issues using recent advances in software integration is explored here. All daylight, thermal and glare analysis were done in DIVA plug-in for Rhinoceros/Grasshopper which has ability to effectively calculate daylight metrics (using the Radiance/Daysim engine) and energy consumption (using the EnergyPlus engine). It can be concluded from experiments that generally, the various size of the louvers were not much different from each other and custom sizes can be selected according to the plan but any alteration in louver's angle and distance from façade were followed by changes in lighting and thermal load of room. In the case of the using fixed louver in design in Tehran's climate, distance between 0 and 13 centimeters and angle between 22.5 to 45 degrees are introduced as the optimum mode.
\end{abstract}

Keywords: optimization, louver-driving mechanism, high-performance architecture, energy efficient architecture, innovative daylighting system, deep-plan building.

\section{SENTEZ VE OPTIMIZASYON DERİN PLAN BINASI YENILİKÇİ GÜN IŞIĞI SISTEMI MEKANIZMASI PANJUR-SÜRÜŞ}

ÖZ

Gün ışığının optimum kullanımı yüksek performanslı mimari ve planlama bir bir importatnt rol oynar. çağdaş binalarda Yenilikçi günışığı sistemleri gibi, gün ışı̆̆1 en iyi seviyeye görsel konfor optimize ve enerji tüketimini azaltarak gibi çeşitli faydalar üretebilir. Bu yazıda, yüksek performanslı mimari gereksinimlerini karşılamak amacıyla derin plan binada gün 1 şı̆̆ı kabulünü optimize etmek için yeni bir 
panjur-sürüş mekanizması geliştirmektir. kağıt Yöntem panjur sürüş mekanizması farklı değerlendirilmesi için deney ve quasiexperimental yaklaşım vurgulamaktadır. Tahran büyükşsehir kağıt vaka çalışması olarak kabul etti. ana hedefi bu gölgeleme cihazı kullanarak enerji taleplerini optimize etmek için daha iyi bir panjur tasarımı standartlarını arama dayanmaktadır. Böylece cepheye farklı panjur genişliği ve açıları ve farklı panjurlar 'mesafe ile 45 farklı olgular analysis.Visual konfor ve enerji verimliliği bütüncül bir yaklaşımla analiz edilmektedir seçilmiştir. Farklı yazılım paketleri ayrıntılı hesaplamaları gerçekleştirmek için gerekli Dahası gün 1şığı ve enerji performansları kombinasyonu her zaman bir sorun olmuştur. Basitleştirilmiş bir yöntem burada keşfedilmeyi yazılımı entegrasyonu son gelişmeleri kullanarak her iki sorunların üstesinden gelmek için. Tüm gün 1şığı, ısı ve parlama analiz DIVA plug-in etkili bir gündüz ölçümleri hesaplamak için yeteneği (Radiance / Daysim motorunu kullanarak) ve (EnergyPlus motorunu kullanarak) enerji tüketimine sahip Rhinoceros / Grasshopper için yapılmıştır. Genellikle, panjurların çeşitli boyut aydınlatma ve termal değişiklikler izledi planı ancak cepheye herhangi bir panjur en açıda değişiklik ve mesafeye göre seçilebilir birbirleriyle ve özel boyutlarda çok farklı değildi deneylerden sonucuna varılabilir odanın yük. 0 ve 13 santimetre ve 22.545 derece arasındaki açı arasında Tahran'ın iklimi, uzaktan tasarım kullanarak sabit panjur durumunda optimum modu olarak tanıtılmaktadır.

Anahtar Kelimeler: optimizasyonu, panjur sürüş mekanizmasl, yüksek performanslı mimarisi, enerji tasarruflu mimarisi, yenilikçi gün ışı̆̆ sistemi, derin plan bina.

\section{INTRODUCTION}

Energy use in buildings accounts for a large percentage of total energy consumption worldwide, which leads to a great amount of $\mathrm{CO}_{2}$ emission to atmosphere.[1] European studies on energy consumption show buildings are responsible for $40 \%$ of energy use and $30 \%$ of $\mathrm{CO}_{2}$ emission. [2] The recent interest in energy efficiency[3] and sustainability has led to the implementation of design strategies[4] in buildings that aim to achieve optimal utilization of daylight with minimum energy consumption for lighting, cooling, and heating.[5] Daylight provides about $110 \mathrm{~lm} / \mathrm{W}$ of solar radiation, while fluorescent lamps produce about $75 \mathrm{~lm} / \mathrm{W}$ of electrical input and incandescent lamps about $20 \mathrm{~lm} / \mathrm{W}$. Therefore, daylighting generates only $1 / 2$ to $1 / 5$ of the heat that equivalent electric lighting produces, thus significantly reducing the building cooling load.[6] In best cases, active and passive systems that use daylight and control components are known to reduce lighting energy consumption by as much as 65\%.[7] The combined savings from reduced lighting and cooling loads can be substantial, since electric lighting can account for $25-40 \%$ of a commercial building's energy requirements.[8] Similarly in Iran, 25\% of the electricity consumption in an office building relates to artificial lighting.[9] Daylight utilization not only causes a lot of lighting energy for building but also it is considered as a source of heat generation in buildings.[10] On the other hand, daylight increase in indoor spaces may cause over heating or glare problems.[11] So, strategies for more daylight inclusion are needed for office interiors within any city (like Tehran), which has a growing demand for electricity. In offices within Tehran, artificial light is considered as the main contributor to the visual environment, even though there is an abundance of daylight during that part of the day known as 'working hours'.[12] It is what daylight control and shading devices are for. Thus the goal of solar controls is to reach equilibrium between the energy load due to solar radiation and the minimum daylight required.[13] A solar control should obstruct direct solar radiation and should take advantage of the diffuse radiation arriving from the sky dome[14] directly or after some internal reflections on the shading device.[13] Shading devices play very important role in building energy demands [15]therefore they are crucially significant in architectural design [16] especially when we want to interact traditional architecture and contemporary architecture.[17]

\section{RESEARCH BACKGROUND}

A daylighting system combines simple glazing with some other element that enhances the delivery or control of light into a space. Whilst ordinary windows deal adequately with some of the daylight needs of a space, there are new technologies and solutions that extend performance beyond that of the conventional 
solutions[18]. There are several ways to classify daylighting systems.one of the classifications is based on how the system works: with or without shading.

Louvers and blinds are traditional daylighting systems that can be applied for solar shading, to protect against and to redirect daylight. They can located on the exterior or interior of a window, or between the panes of glass.[18] Their applications range from simple fixed ventilators to window shutters to complex airflow control devices in double skin facades. The evolution of louver technology continues today with increasing use in modern buildings. Louvers are generally described as a system of horizontal or vertical slats that are angled to admit light and air and keep out rain, direct sunshine, and noise. A louvered opening has series of such slats integrated into a frame. The louvers are opened and closed by rotation about a pivot, supported from the frame. The angle of the louver slats can be adjusted through manual or mechanical operation.[19] Design of such louver systems is well developed, as in the excellent treatise by the Olgyay brothers.[20] This list of studies generally summarizes what has been covered by the efforts of previous researchers.

Tzempelikos and Athienitis[21] evaluated the effects of shading device characteristics, shading control and glazing area on cooling and lighting energy needs for a building located in Montreal; an exterior roller blade has been considered as shading device.

Stazi et al [22] studied the louver shading devices through the analysis of the impact of adopting different materials, length of slats and vertical distance between slats.

Datta[23] analyzed the influence of fixed horizontal louver shading devices on thermal performance of a building for Italian climates, considering a simple 2-zone building with high external wall U-value (1.691Wm_2 K_1); the study focused on a louver shading device applied to the south-facing window.

Palmero-Marrero and Oliveira [24] investigated the effects of louver shading devices applied to a building for different climates (Mexico, Cairo, Lisbon, Madrid, London), assessing their impact on indoor thermal conditions and energy demand compared to a building without shading devices.

Exterior louvers are usually made of galvanised steel, anodised or painted aluminium, or plastic (PVC) for high durability and low maintenance.

The slats can be either flat or curved. Slat size varies with the location of the blinds: exterior, interior, or between the panes in a double-paned window. Exterior slats are usually between 50 and $100 \mathrm{~mm}$ wide; interior slats are usually 10 to $50 \mathrm{~mm}$ wide.[18] Louvers and blinds can be used in all orientations and at all latitudes and can be added to a window system whenever necessary. Exterior blinds affect the architectural and structural design of a building; interior blinds have less impact. In practice, horizontal louvers and blinds are generally used on all building orientations, and vertical blinds are predominantly used on east- and west-facing windows. Advanced designs have different requirements from conventional blinds.[18]

Louvers and blinds may obstruct, absorb, reflect and/or transmit solar radiation (diffuse and direct) to a building's interior. Their effect depends on the position of the sun and their location (exterior or interior), slat angle, and slat surface reflectance characteristics. Thus, the optical and thermal properties of a window with louvers or blinds are highly variable.[18]

The purpose of this study was to identify the impact of different light transmission patterns from building's façade in the thermal and visual comfort of the interior space and use of proper transparent and solid surfaces in the outer shell of the building with the aim of achieving optimal daylight also introduction of Standard Louvre Ordering tailored to the needs of the building. 
Experimental and quasi-experimental research strategy was used in this study and simulation model was used as technique to study the sample's behavior. Diva software was used as simulation tool. DIVA is a plug-in for rhinoceros, which stands for "Design, Iterate, Validate and Adapt"[25] This software allows for environmental analyses in Rhinoceros and its Grasshopper components. It integrates Radiance/Daysim for daylight calculations and EnergyPlus for thermal analyses. Both Daysim and EnergyPlus have been extensively used and validated in research and practice, and their integration in Grasshopper allows them to be accessible to a wider range of users [26]

\section{METHODOLOGY}

This study evaluates daylight illuminance and thermal performance and glare condition of different louvers cases by using Diva as the daylight modeling tool and an interface for energy plus modeling tool.

\section{WORK PLANE ILLUMINANCE}

Work plane Illuminance as an indicator of daylight, is used to check the quality of daylight in spaces. Different places need different amount of WPI due to different activities in different places.[27] WPI should be 500 Lux to have enough potential for reading and writing. Acceptable range for Work Plane Illuminance is $300-500$ lux for offices.[28] If Work Plane Illuminance is less than 100 lux, the office room is considered too dark for paper and computer work. If the amount of work plane illuminance is between 100-300 lux, the office room has acceptable range of daylight for computer work but this is not acceptable for paper work. If work plane illuminance is between 300-500 lux, this amount of Work Plane Illuminance is acceptable for paper work and ideal for computer work.[9] The light of office rooms suitable for paper work and too bright for computer when Work Plane Illuminance is higher than 500 lux.[29]

\section{SIMULATION MODEL}

For the purposes of this paper, a standard Office model was constructed as detailed in Figure.1. Light sensors are placed on a $0.25 * 0.25 \mathrm{~m}$ grid in height of $0.75 \mathrm{~m}$ from floor.

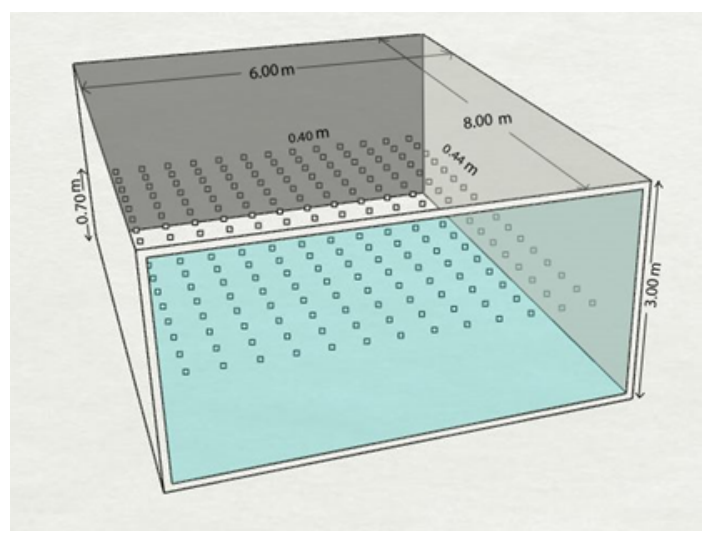

Figure 1. analysis model in DIVA

All simulations are performed in the Tehran, Iran climate with no exterior obstructions. All the material settings are chosen from Diva default material. Five users share the space. Exterior walls are modeled as having a U-Value of $0.21 \mathrm{~W} / \mathrm{m} 2 \mathrm{~K}$. Windows have a visual transmittance of 0.508 , a solar heat gain coefficient of 0.4 and a U-Value of $0.55 \mathrm{~W} / \mathrm{m} 2 \mathrm{~K}$. Solar reflectance and visual reflectance of louvers is 0.75. Thermal material setted from ASHARE ZONE5 which is near to Tehran's climate and daylight material detail is shown in table. 1 .

Table1 :Daylight model's material setting

\begin{tabular}{|l|l|l|l|l|l}
\hline Roughn & Specular & BLU & GREE & RED & Materi \\
\hline
\end{tabular}




\begin{tabular}{|l|l|l|l|l|l}
\hline ess & ity & $\mathrm{E}$ & $\mathrm{N}$ & & al \\
\hline 0 & 0 & 0.7 & 0.7 & 0.7 & $\begin{array}{c}\text { Ceiling } \\
70\end{array}$ \\
\hline 0 & 0 & 0.2 & 0.2 & 0.2 & $\begin{array}{c}\text { Floor } \\
20\end{array}$ \\
\hline 0 & 0 & 0.5 & 0.5 & 0.5 & Wall50 \\
\hline 0.2 & 0.3 & 0.8 & 0.8 & 0.8 & $\begin{array}{c}\text { Alumi } \\
\text { num I }\end{array}$ \\
\hline & & & $\begin{array}{l}\text { Visual } \\
\text { transm } \\
\text { issivit } \\
\mathrm{y}\end{array}$ & $\begin{array}{c}\text { Visual } \\
\text { transm } \\
\text { ittance }\end{array}$ & $\begin{array}{c}\text { Glazin } \\
\mathrm{g} \\
\text { double } \\
\text { pane } \\
\text { clear }\end{array}$ \\
\hline & & & $87 \%$ & $80 \%$ & \multicolumn{2}{c}{} \\
\hline
\end{tabular}

In order to optimize louvers design, their main parameters selected as variable factors are their width, angle, and distance from façade. Their distance from each other supposed to be same as their width because lower than that limited view and more than that had glare problem. (Figure.2)
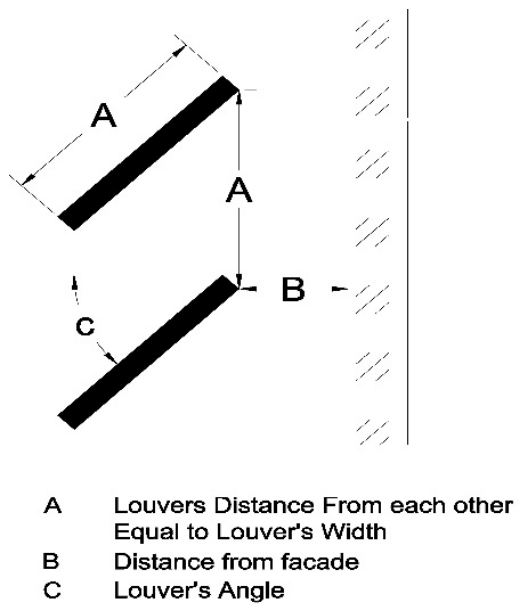

Figure 2 Louver variable design parameters

\section{LOUVER'S DIMENSION (PARAMETER A)}

To select the most optimal mode it's essential to study available louver's dimensions. The available aluminum louver width is from 8 centimeter up to 60 centimeter. Louvers' form has been considered rectangular in the study. $10 \mathrm{~cm}, 35 \mathrm{~cm}$ and $60 \mathrm{~cm}$ have been selected as louver's width samples and they are studied and analyzed.

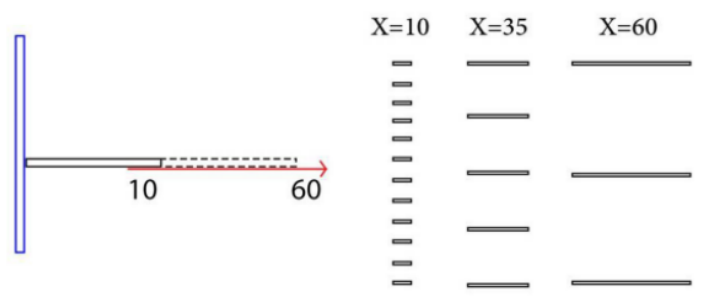


Distance of slats from each other is the part of the facade that is between the Louvers and can be seen from the facade and seeing the outside and view is possible from this space. the amount of opening depends on the angle of the Louvers. Louver at the angle of 0 degrees has the most opening space and has full outside view and it's reduced as the angle increase toward 15, 30 and 45 until it is completely closed at 90 . The value of this opening also has a large impact on air pressure in the window surrounding.

In order to respect and preserve the opening, the distance between the Louvers and their width is intended equal in simulation.(Figure 3.)

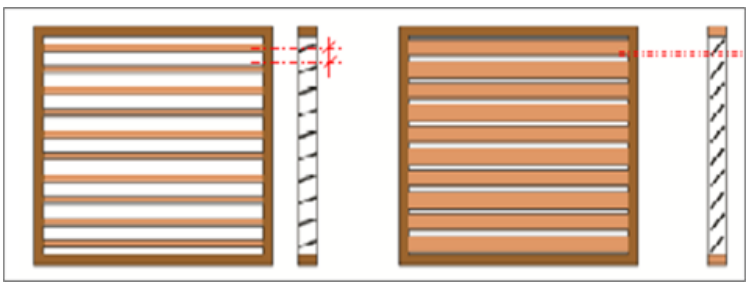

Figure 3: relation between opening space and louver angle

\section{LOUVERS' DISTANCE FROM FAÇADE (PARAMETER B)}

The other parameter of the study is distance of louvers from façade. The samples of this factor which was studied are $0 \mathrm{~cm}, 13 \mathrm{~cm}, 25 \mathrm{~cm}, 37 \mathrm{~cm}$, and $50 \mathrm{~cm}$.

\section{LOUVER'S ANGLE( PARAMETER C)}

Based on previous studies that had been advised preventing angles greater than 45 in the Louver design, in this simulation variable angle were considered from 0 to 45 degrees. Among the range of 0 to 45 degree three samples were chosen. There are $0^{\circ}, 22.5^{\circ}$ and $45^{\circ}$.

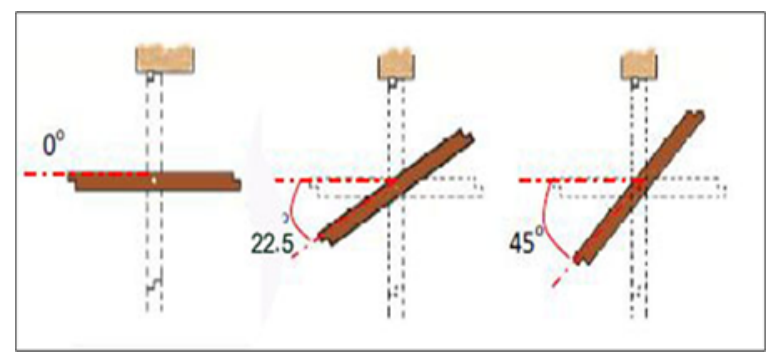

Figure 4 Chosen angle samples

\section{DATE AND TIME OF SIMULATIONS}

Analysis of the amount of heating and cooling energy needs and glare were done annual but Due to the high amount of data, illuminance analysis was done on winter solstic and summer solstic.

Simulation of heat and glare were done in 45 different louver's situations and dimensions. illuminance analyze was done in 21 st of December and June, each one in 45 states that was 90 position in total. 


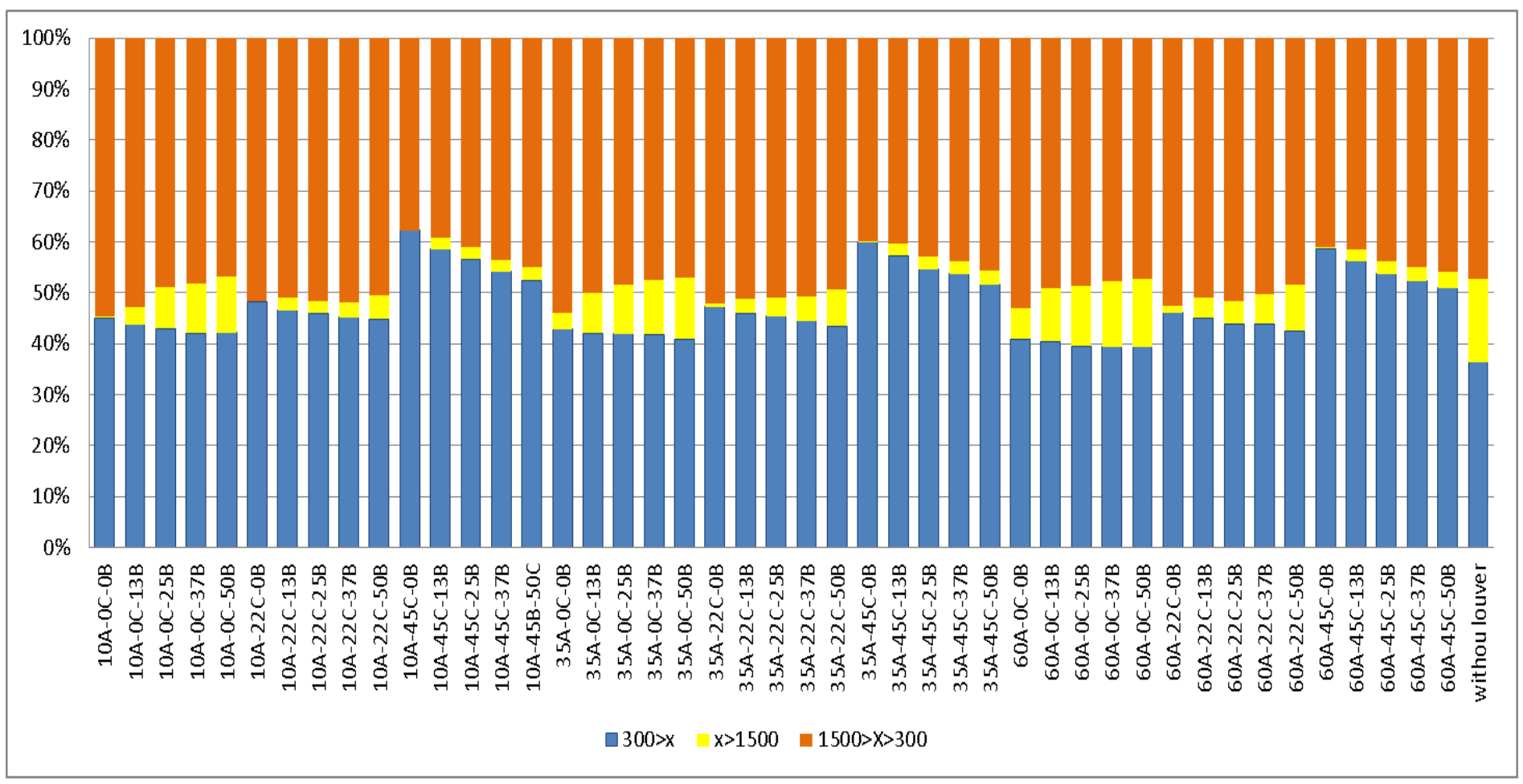

Figure 5 The cases simulation results at 9oclock of 21 thJUNE in terms of illumination evaluation levels: " $300>x$ ", " $\mathrm{x}>1500$ " and " $1500>\mathrm{x}>300$ " areas. The numbers before A,B,C are sample amount. For example 10A-0C-0B means a louver with $10 \mathrm{~cm}$ width and $0^{\circ}$ angle and 0 amount of distance from facade 


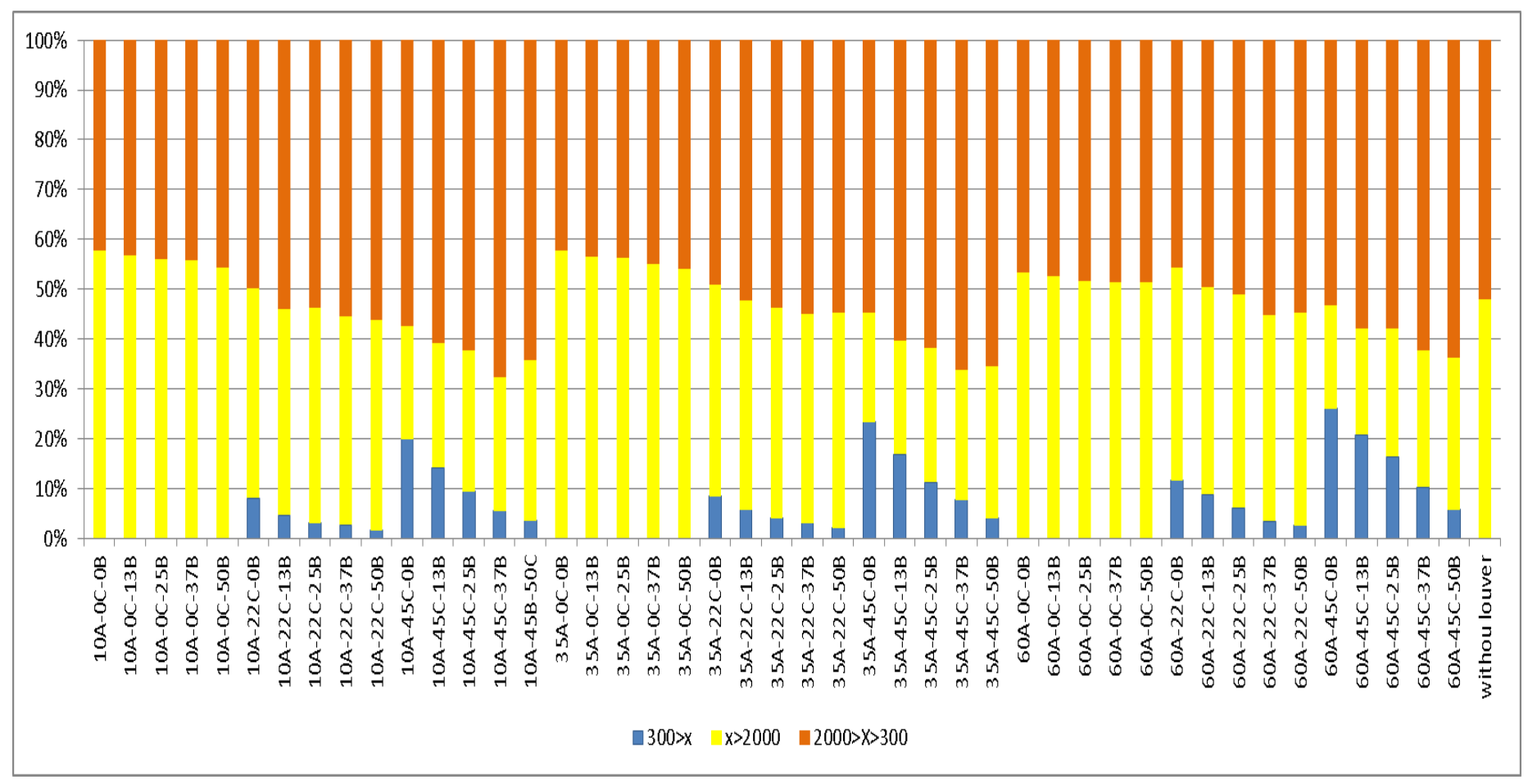

Figure 6 The cases simulation results at 12oclock of 21 th December in terms of illumination evaluation levels: “ $300>x$ ", " $x>1500$ " and " $1500>x>300$ " areas. The numbers before A,B,C are sample amount. For example 10A-0C$0 \mathrm{~B}$ means a louver with $10 \mathrm{~cm}$ width and $0^{\circ}$ angle and 0 amount of distance from facade

\section{RESULTS AND DISCUTION}

In Diagram of the optimal light illuminance at 9 o'clock of 21 st June optimum case happens when more percentage of data are in range of 300 lux to 1500 lux. According to this diagram the 22 degree is more desirable than 0 degree and 0 degree is more desirable than 45 . With both 0 and 22 degree angels by increasing louvers' distance from façade the presentage of optimum illuminance decreses but it becomes reverse in $45^{\circ}$ angle.

In Diagram of the optimal light illuminance at 12 o'clock of 21 st december optimum case happens when more percentage of data are in range of 300 lux to 2000 lux. According to this diagram the 45 degree is more desirable than 22 degree and 22 degree is more desirable than 0 . In all angels by increasing louvers' distance from façade the presentage of optimum illuminance increases. The main conclusion that can be deduced from above is infection of louvers dimensions and importance of louver's angle in room's illuminance. 


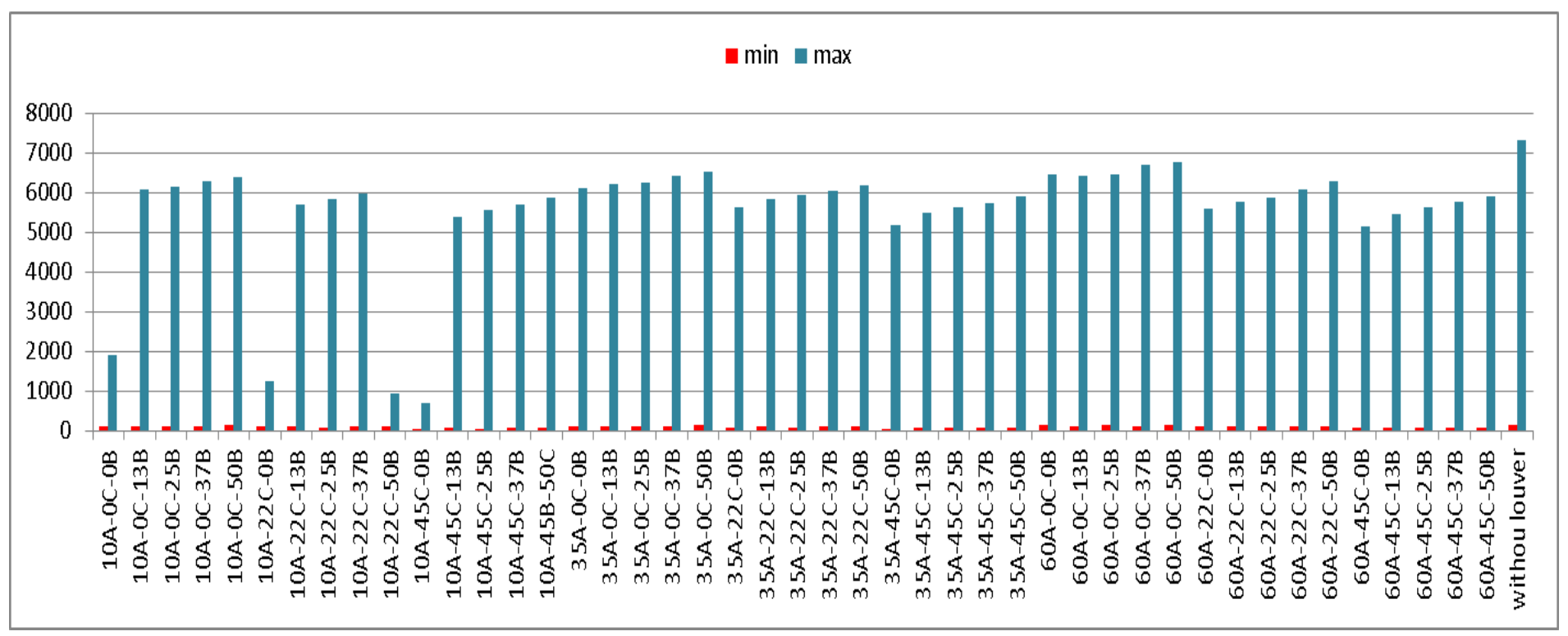

Figure 7 The cases simulation results at 9oclock of 21 th JUNE in terms of minmum and maximum illumination The numbers before A,B,C are sample amount. For example $10 \mathrm{~A}-0 \mathrm{C}-0 \mathrm{~B}$ means a louver with $10 \mathrm{~cm}$ width and $0^{\circ}$ angle and 0 amount of distance from facade

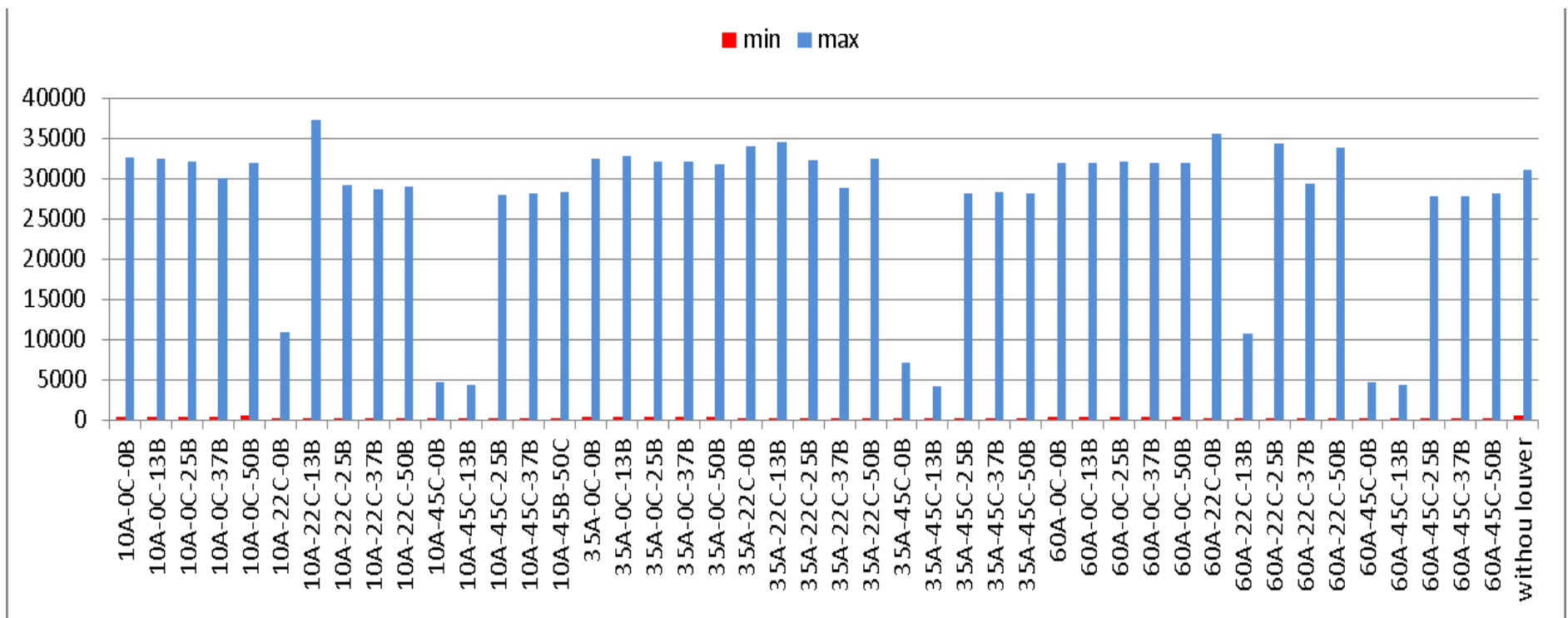

Figure 8 The cases simulation results at 12 oclock of 21 th December in terms of minmum and maximum illumination The numbers before A,B,C are sample amount. For example $10 \mathrm{~A}-0 \mathrm{C}-0 \mathrm{~B}$ means a louver with $10 \mathrm{~cm}$ width and $0^{\circ}$ angle and 0 amount of distance from facade

In Diagram of the minimum and maximum of room's illuminance, contrast of light in the room and the maximum and minimum of room's illuminance could be studied. According to diagram in 9 a.m. of 21 st June maximum and minimum both reduced by increasing angle from zero to 45 but it's reverse by increasing louvers' distance from façade.

On 21 December lighting condition for different distances and angles have somewhat chaotic graph But generally $45^{\circ}$ angle outperformed the other two angles. 45 degree angle for each of the three sizes with louvers' distance of $0 \mathrm{~cm}$ and $13 \mathrm{~cm}$ from facade have acceptable behavior. 


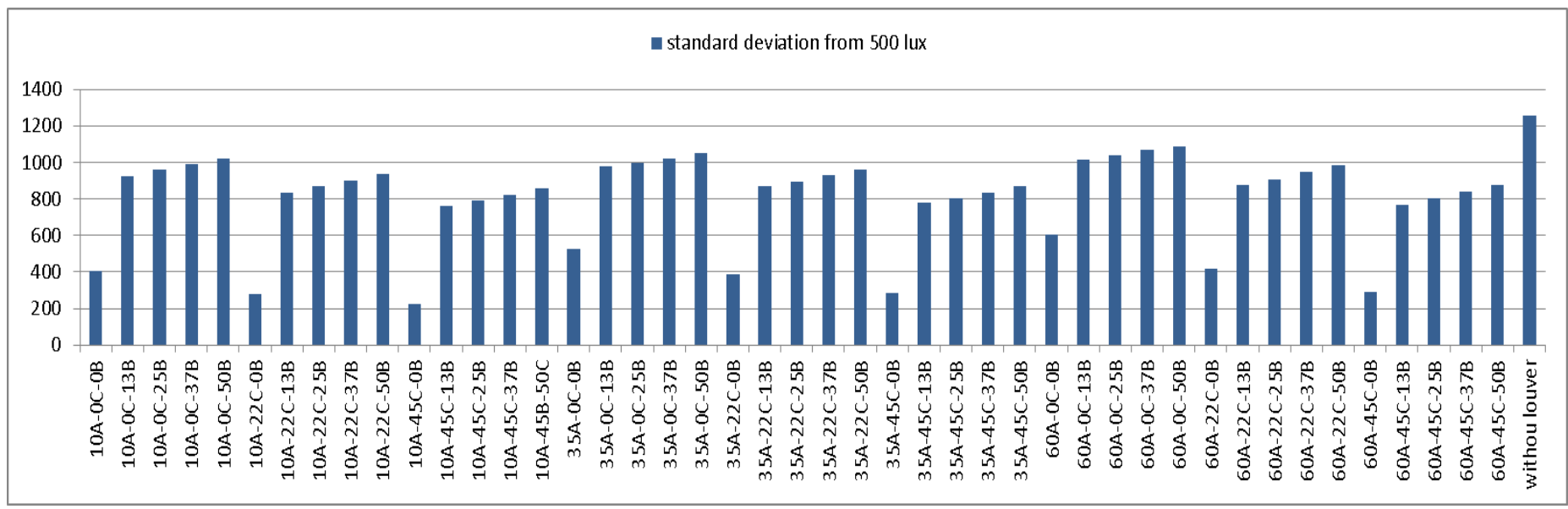

Figure 9 the iluminance's deviation from 500 lux for 9 oclock of 21 JUNE

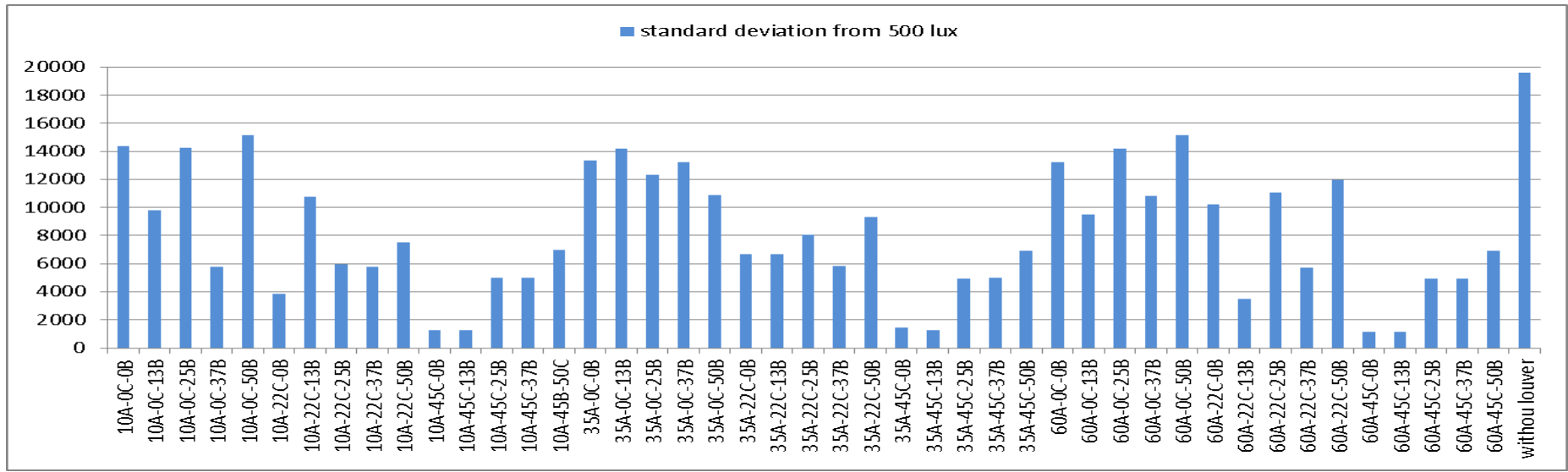

Figure 7 the iluminance's deviation from 500 lux for 12 oclock of 21 DECEMBER

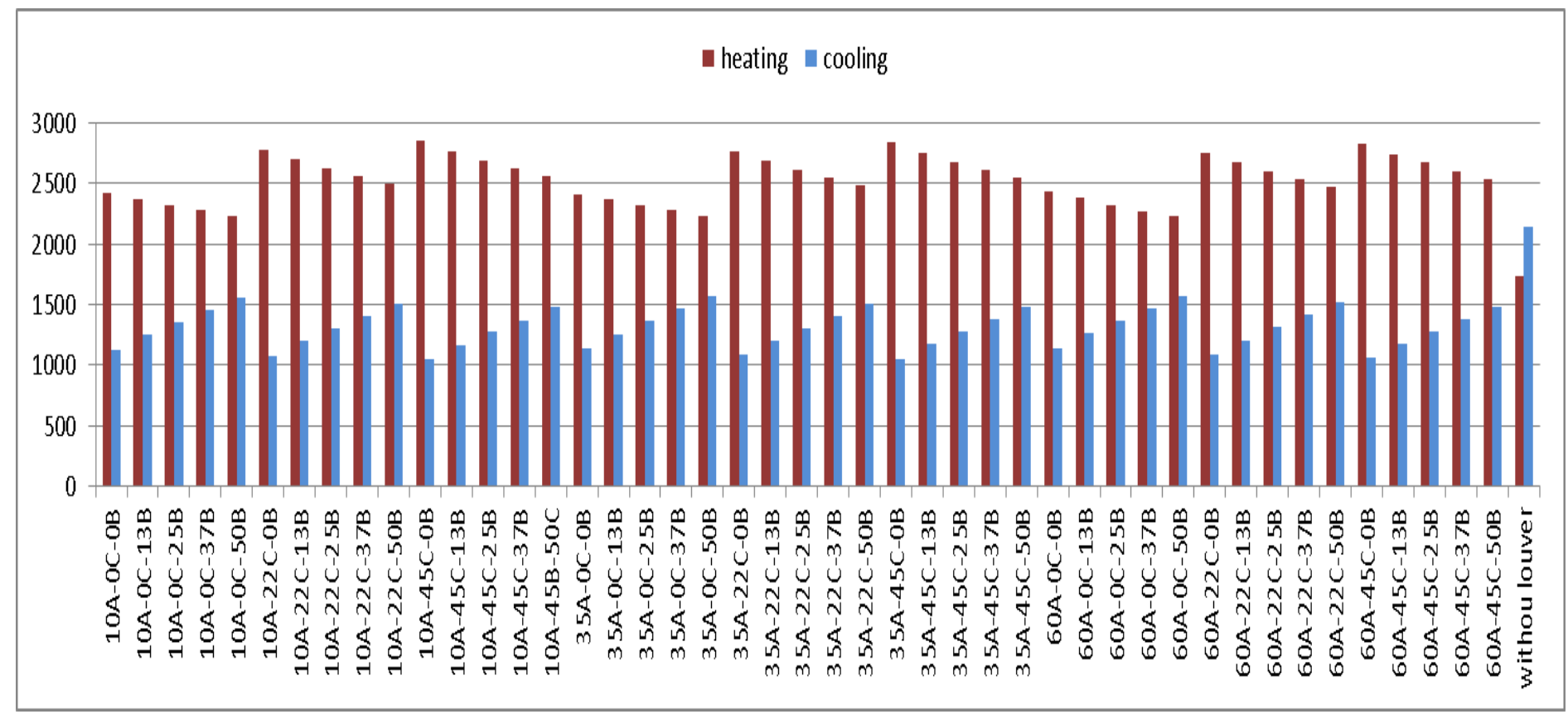

Figure 11: The cases annual heating and cooling loads simulation results (Kwh)

Submit Date: 10.02.2016, Acceptance Date: 25.03.2016, DOI NO: 10.7456/1060ASE/018 


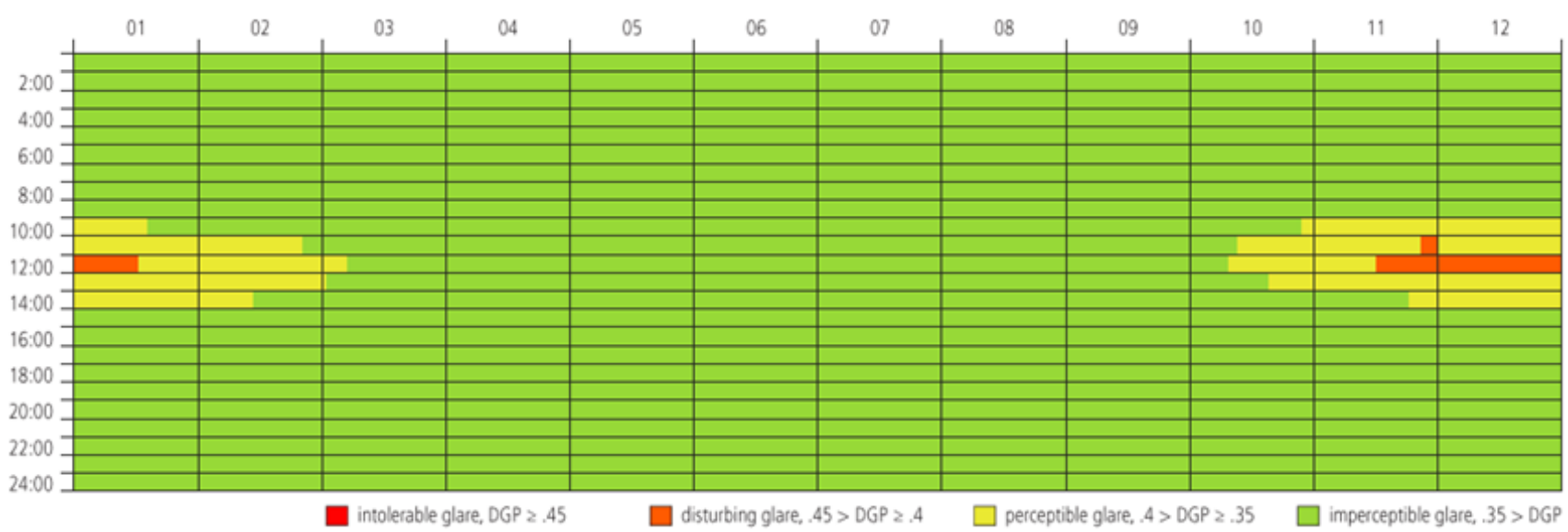

Figure 8: the selected worst condition of annual glare of cases

For better comparison the diagram of data's standard deviation from 500 lux as an optimum amount was drawn.

This diagram in 21st June shows that louvers' performance by increasing angle from 0 to 45 and decreasing distance from 50 to 0 becomes better and there is much difference between 0 distances from facade with other amounts.

The diagram of 21 st December at 12 A.m. has many rises and falls but generally $45^{\circ}$ angle is better than $22^{\circ}$ and $22^{\circ}$ is better than $0^{\circ}$. But $22^{\circ}$ angle in some distances is Undesirable than $0^{\circ}$ angle. In generally $45^{\circ}$ angle with all dimensions in distance of $0 \mathrm{~cm}$ till $13 \mathrm{~cm}$ from facade has a good performance.

In annual heating and cooling load diagram by increasing angle of louvers heating load increases and cooling load decreases and by increasing the louvers' distance from facade heating load decreases and cooling load increases But changing louver width does not make more difference in cooling and heating load.

Result of glare analyze for all cases is almost identical and is imperceptible glare but in 12 a.m. of winter days partly disturbing glare could be seen.

Totally it could be concluded from diagrams that louver's width has not saleint effect on illuminance and thermal load of room and different dimensions could be selected according to design but the most important factors in louver design is angels and after that louvers' distance from facade.

Table 2: optimum cases of each figure

\begin{tabular}{|c|c|c|c|c|c|c|c|c|}
\hline & \multicolumn{6}{|c|}{ 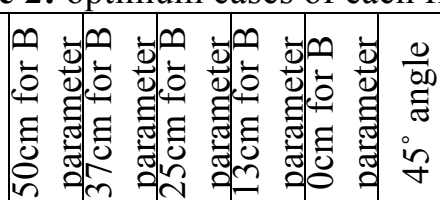 } & 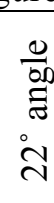 & $\begin{array}{l}\stackrel{0}{0 D} \\
\stackrel{\Xi}{\Xi} \\
0\end{array}$ \\
\hline Figure 5 & & & & & $*$ & & $*$ & $*$ \\
\hline Figure6 & $*$ & $*$ & & & & * & & \\
\hline Figure7 & & & & & $*$ & $*$ & $*$ & \\
\hline Figure8 & & & & $*$ & $*$ & * & & \\
\hline Figure9 & & & & & $*$ & $*$ & $*$ & \\
\hline $\begin{array}{c}\text { Figure } 1 \\
0\end{array}$ & & & & $*$ & $*$ & * & $*$ & \\
\hline
\end{tabular}




\begin{tabular}{|c|c|c|c|c|c|c|c|c}
\hline $\begin{array}{c}\text { Figure } \\
1\end{array}$ & & & & $*$ & $*$ & & & $*$ \\
\hline
\end{tabular}

From pluralization table on top could be concluded that if the fixed louvers has been used in design the optimum case would be the angle of $22.5^{\circ}$ till $45^{\circ}$ and louvers' distance from façade between $0 \mathrm{~cm}$ and 13 $\mathrm{cm}$. but if the movable louvers has been used in design the optimum case would be more louvers' distance from with $45^{\circ}$ angle in winter and less louvers' distance from façade and smaller angle in summer.

\section{CONCLUSION}

Studies show that Tehran has high Daylight potential in the south So that after preventing and disturbing the direct sun lights in summer still could receive proper light in interior space and in winter that the use of solar radiation to heat the building is recommended also the interior lighting is provided from it.

In fact, in Tehran Daylight Illuminance on the vertical plane in the south is at the level which may cause the glare problem for the residents, in condition of using large area of transparent surfaces.

However shading devices by controlling the daylight can make using the daylight in Tehran on vertical surfaces in the south efficient.

Purpose of this study was to identify the impact of different light transmission patterns from building's façade in the thermal and visual comfort of the interior space and use of proper transparent and solid surfaces in the outer shell of the building. In order to reach these goals among the daylight systems, the louvers which are adjusted the pattern of exposure in space, were selected for review.

In order to study different patterns among various size and angles of the Louvers some samples from range of each factor were chosen So 45 cases with variety of angles sizes and different distances from façade were selected for experimenting.

A single model simulated in DIVA and all thermal and lighting and glare conditions of the space were studied synchronously in it.

Generally these results were obtained from simulated samples that although in summer daylight cause undesirable and unwanted heat in interior space but the depths of the rooms are faced with Light deficiencies because of the high radiation angle of solar rays.

Conversely, in the winter entering direct light into space not only reduces the heat load and helps heating space but also causes glare and visual problems. For this reason interactive and dynamic design is more efficient than designing with fixed objects.

In general, the various size of the Louvers were not much different from each other and custom sizes can be selected according to the plan but any alteration in louver's angle and distance from façade were followed by changes in lighting and thermal load of room.

In the case of the using fixed Louver in design, distance between 0 and 13 centimeters and angle between 22.5 to 45 degrees are introduced as the optimum mode.

If the movable louver system is used in design, in winter the optimum condition is angle of 45 degree and far louver distance from façade and in summer the closest distance of louvers from façade is optimum condition. 


\section{REFRENCES}

1. Mahdavinejad, M., et al. Horizontal distribution of illuminance with reference to window wall ratio (wwr) in office buildings in hot and dry climate, case of iran, tehran. in Applied Mechanics and Materials. 2012.

2. Maccari, A. and M. Zinzi, Simplified algorithms for the Italian energy rating scheme for fenestration in residential buildings. Solar Energy, 2001. 69: p. 75-92.

3. Mahdavinejad, M., et al., The Strategies of Outspreading Smart Materials in Building Construction Industry in Developing Countries; Case Study: Iran. International Conference on Intelligent Building and Management Proc. of CSIT, 2011. 5.

4. Mahdavinejad, M., M. Ghasempourabadi, and H. Ghaedi. The role of form compositions in energy consumption of high-rise buildings (case study: Iran, Tehran). in Advanced Materials Research. 2012. Trans Tech Publications.

5. Mahdavinejad, M., et al., Proposing a Flexible Approach to Architectural Design as a Tool for Achievement Eco-Friendly Multi-Purpose Buildings. Advanced Materials Research, 2012: p. 622-623.

6. Kandilli, C. and K. Ulgen, Solar illumination and estimating daylight availability of global solar irradiance. Energy Sources, Part A, 2008. 30(12): p. 1127-1140.

7. Hasdemir, B., A new method for the estimation of lacking daylight illumination data by using available meteorological data. 1995, Ph. D. Thesis, Middle East Technical University, Ankara, Turkey.

8. Mahdavinejad, M. and R. fallahtafti, Optimisation of Building Shape and Orientation for Better Energy Efficient Architecture. International Journal of Energy Sector Management, 2015. 9(4): p. 593618.

9. Mahdavinejad, M., M. Garaati, and A. Yazhari Kermani, Daylight Parameters and Operation Quality; Case Studies: Public Office Buildings in Kerman, Iran. Journal of Energy Technologies and Policy, 2014. 4(9): p. 29-34.

10. Mahdavinejad, M., S. Matoor, and A. Dorodgar, Recognition of light-openings in Iranian mosques' domes With reference to climatic properties. International Journal of Architectural Engineering \& Urban Planning, 2011. 17(4): p. 41-48.

11. Mahdavinejad, M., M. Nansorpoor, and M. Hadiyan, Courtyard Phenomena in Contemporary Architecture of Iran. Journal of Studies on Iranian-Islamic City, 2014. 4(15): p. 35-45.

12. Mahdavinejad, M., S. Matoor, and R. Fayaz, Vertical Illuminance Measurement for Clear Skies in Tehran. Armanshahr, 2012. 4(8): p. 11-19.

13. Jorge, J. and J. Puigdomènech, A daylight criterion on solar controls for comparing sky radiance models. Building and Environment, 1996. 31(3): p. 225-232.

14. Mahdavinejad, M., et al., Estimation of Daylight Availability and Illuminance on Vertical South Facing Surfaces in Tehran. Advanced Materials Research, 2012: p. 518-523.

15. Mahdavinejad, M. and m. pourfathollah, New Lighting Technologies and Enhancement Sense of Belonging in Case of Tehran Buildings Facades. Journal of Human Geography Research, 2015. 47(1): p. 131-141.

16. Mahdavinejad, M. and A. Moradchelleh, Problems and tendencies of the development of the architectural sciences: Culture research aspect. Middle-East Journal of Scientific Research, 2011. 10(6): p. 677-682.

17. Mahdavinejad, M., A. Doroodgar, and A. Moradchelleh, The impacts of revivalist trends on the contemporary architecture of Iran (1977-2011). Middle-East Journal of Scientific Research, 2012. 11(2): p. 176-183.

18. Aschehoug, Ø., et al., Daylight in Buildings: A Source Book on Daylighting Systems and Components. A Report of IEA SHC Task 21, ECBCS Annex 29. 2000: International Energy Agency, IEA, Solar Heating and Cooling Programme, SHC, Energy Conservation in buildings and Community Systems Programme, ECBCS.

19. Chandrashekaran, D., Air flow through louvered openings: Effect of louver slats on air movement inside a space. 2010: University of Southern California.

20. Olgyay, A. and V. Olgyay, Solar control \& shading devices. 1976: Princeton University Press. 
21. Tzempelikos, A. and A.K. Athienitis, The impact of shading design and control on building cooling and lighting demand. Solar Energy, 2007. 81(3): p. 369-382.

22. Stazi, F., et al., Comparison on solar shadings: Monitoring of the thermo-physical behaviour, assessment of the energy saving, thermal comfort, natural lighting and environmental impact. Solar Energy, 2014. 105: p. 512-528.

23. Datta, G., Effect of fixed horizontal louver shading devices on thermal perfomance of building by TRNSYS simulation. Renewable energy, 2001. 23(3): p. 497-507.

24. Palmero-Marrero, A.I. and A.C. Oliveira, Effect of louver shading devices on building energy requirements. Applied Energy, 2010. 87(6): p. 2040-2049.

25. Solemma. DIVA for Rhino. 2015; Available from: http://diva4rhino.com.

26. Palmero-Marrero, A.I. and A.C. Oliveira, Evaluation of a solar thermal system using building louvre shading devices. Solar energy, 2006. 80(5): p. 545-554.

27. Kaufman, J.E. and H. Haynes, IES lighting handbook; reference volume and application volume. 1981.

28. CIBSE, code for interior lighting. 1994, London, UK: Chartered Institution of Building Services Engineers (CIBSE).

29. Dubois, M.-C., Impact of Solar Shading Devices on Daylight Quality. Department of Construction and, 2001. 